\title{
Strategi Creative Director Dalam Pembuatan Aplikasi Metro Traffic
}

\author{
Anggara Anugrah Prakoso ${ }^{1}$, Shulhuly Ashfahani \\ ${ }^{1.2}$ Program Sarjana Ilmu Komunikasi \\ Sekolah Tinggi Ilmu Komunikasi Indonesia Maju \\ Jln. Harapan No.50, Lenteng Agung - Jakarta Selatan 12610 \\ Telp: (021) 78894045, Email: ' ${ }^{1}$ sherlockholmes1308@gmail.com, ${ }^{2}$ shulhuly.a@gmail.com
}

\begin{abstract}
Abstrak
Aplikasi "Metro traffic" adalah terobosan baru bagi para pengguna jalan khusus nya pengguna jalan jarak jauh. Aplikasi yang di keluarkan oleh salah satu stasiun tv yaitu METRO TV digunakan sebagai branding untuk menarik minat dan meningkatkan citra di hadapan masyarakat Indonesia. Aplikasi ini dibuat dengan sebuah konsep kreatif sehingga dapat memudahkan pengguna yanng ingin berpergian dengan jarak yang jauh. Sifat penelitian ini adalah Kualitatif, dengan studi deskriptif. Jenis dan tehnik pengumpulan data adalah data primer yang diperoleh dari wawancara. Sementara data sekunder diperoleh dari data yang berbentuk buku, web, artikel. Hasil penelitian. Dalam pembuatan aplikasi ini terdapat tiga tahapan yang harus dilakukan seperti Insight (observasi) setelah tahapan pertama sudah dilakukan selanjutnya masuk ke tahapan kedua yaitu idea (ide) kemudian setelah proses idea (ide) sudah dilakukan lalu masuk ke tahapan terakhir yaitu act (aksi) tahapan ini adalah tahapan produksi sekaligus tahapan terakhir dalam pembuatan sebuah aplikasi Traffic. Ketiga tahapan ini sangatlah penting untuk dilakukan karena tiga tahapan tersebut merupakan sebuah pondasi dalam membuat suatu produk baik itu membuat aplikasi maupun iklan pada media sosial.
\end{abstract}

Kata Kunci: Pembuatan, Strategi Kreatif, Aplikasi.

\begin{abstract}
Abstrack
The "Metro traffic" application is a new breakthrough for its road users specifically for long distance users. Applications that are issued by one TV station that is used as a branding METRO TV to attract interest and enhance the image in front of the people of Indonesia. This application is created with a creative concept that can facilitate users who want to travel with a long distance. The nature of this research is qualitative, with descriptive study. Types and data collection techniques are primary data obtained from interviews. While the secondary data obtained from the data in the form of books, web, articles. Research result. In making this application there are three stages that must be done such as Insight (observation) after the first stage has been done then go to the second stage of the idea (idea) and then after the idea (idea) has been done and go to the last stage of action (action) this is the stage of production as well as the last stage in making an application traffic. These three stages are very important to do because these three stages is a foundation in making a product whether it makes the application or advertising on social.
\end{abstract}

Keyword: Create, Strategic Creative, Aplication. 


\section{Jurnal Ilmiah Komunikasi}

\section{Pendahuluan}

Di dalam dunia periklanan saat ini banyak sekali macam media yang di pakai. Pada awal kemunculannya, iklan hanya menggunakan pesan yang disampaikan dari mulut ke mulut atau disebut word of mouth. Kemudian cara beriklan mulai berkembang, yaitu melalui tulisan dikertas dengan cara mendesain kertas dengan membuat sebuah tulisan yang menarik dan sedikit gambar sebuah produk yang akan diiklankan. Berdasarkan buku Advertising, Moriarty "premis untuk merespon, didalamnya terdiri dari manfaat yang menekankan pada apa yang dapat dilakukan produk unntuk pengguna dengan menerjemahkan ciri produk atau atributnya kedalam sesuatu yang berguna bagi konsumen". 9 yang rasional dan berorientasi konsumen dengan menggunakan alasan logis yang mungkin menarik calon konsumen dan memotivasi mereka Di zaman yang semakin modern ini, cara beriklan pun semakin maju, iklan bukan lagi sekadar dari mulut ke mulut ataupun tulisan, tetapi banyak media yang dapat digunakan sebagai sarana beriklan, seperti media cetak (koran, majalah, brosur dll), televisi, radio, bahkan saat ini banyak iklan yang menggunakan media internet. Namun saat ini setiap perusahaan pasti menggunakan strategi lain dalam beriklan untuk menarik minat masyarakat agar produk atau jasa yang dipromosikan bisa di kenal dan di beli oleh khalayak. Saat ini media yang sering digunakan sebagai alat untuk promosi adalah media internet. Menurut sudiana yang dikutip oleh widyatama bahwa "iklan merupakan bagian dari reklame yang berasal dari kata perancis, yaitu reclame yang berarti meneriakkan berulang-ulang". ${ }^{7}$

Tujuan perusahaan menggunakan internet dalam kegiatan bisnisnya pada awalnya adalah sekedar untuk menyediakan informasi mengenai suatu produk kepada khalayak. Weber menjelaskan: "the social media is a new world of unpaid media, created by individuals and companies on internet". Dari kutipan diatas penulis menerjemahkan sebagai berikut: sosial media adalah dunia baru media yang belum dibayar, yang diciptakan oleh individu dan perusahaan di internet. ${ }^{8}$ Perusahaan membangun dan menggunakan situs web atau website dengan tujuan tidak lebih sebagai katalog atau brosur elektronik yang dapat di akses secara online yang bertujuan menyediakan informasi. Situs web di internet adalah tempat informasi untuk para pengguna internet dari berbagai belahan dunia. Dalam sejarah teknologi komunikasi tidak ada media yang mampu menandingi internet dalam hal pertumbuhan jumlah penggunanya. Menurut Suyanto, "Aplikasi dari keterampilan seni dan komunikasi untuk kebutuhan bisnis dan industri". Di negara maju, internet mengalahkan seluruh media sebagai referensi untuk mendapatkan informasi. Internet dapat didefinisikan sebagai " $a$ world means of exchanging information and communicating through a series of interconnected computers (suatu metode yang mendunia untuk saling tukar menukar informasi dan berkomunikasi melalui komputer yang saling terkoneksi). Beberapa tahun ini siapa saja yang memiliki komputer dan modem dapat mengakses internet dan menjadi bagian dari jaringan komunikasi dunia. Namun saat ini memiliki situs web di internet adalah suatu keharusan. "Peran situs web sebagai alat untuk berpromosi kemudian berubah dengan sangat cepat. Di zaman globalisasi media internet banyak di gandrungi oleh masyarakat Indonesia dan media internet sangat mudah sekali di jangkau". ${ }^{1}$

Saat ini masyarakat Indonesia melakukan kegiatan maupun beriklan melalui media internet di bandingkan beriklan secara langsung. Karena beriklan melalui internet memiliki beberapa kenggulan dibandingkan media konvensional lainnya, hal ini seperti yang diungkapkan Morissan. Menurut "internet sebagai media iklan dan promosi memiliki sejumlah keunggulan namun juga memiliki kelemahan". ${ }^{1}$ Di era teknologi ini seseorang mampu berkomunikasi dengan seseorang lainnya dengan keluarga, teman ataupun kerabat dengan Feedback yang cukup cepat di bandingkan berkomunikasi melalui surat menyurat dengan 


\section{Jurnal Ilmiah Komunikasi}

Feedback yang cukup lama. Selain itu Internet mampu memperluas wawasan dengan mengetahui fenomena yang sedang terjadi saat ini dan yang terjadi di masa lalu. Media internet mampu mempermudah seseorang untuk mencari teman di berbagai belahan dunia, dengan aplikasi untuk mencari teman seperti G-mail, Yahoo, Facebook, Twitter, Instagram, Skype, dan lain-lain.

Hanya saja kekurangan berkomunikasi melalui internet yaitu tidak tersedianya data yang akurat mengenai jumlah audiens pengguna internet atau jumlah orang yang berkinjun pada suatu situs web dan sulitnya mengetahui karakteristik audiens. Proses membuka situsweb untuk mendapatkan informasi (download) terkadang berjalan lambat. Hal biasanya terjadi jika suatu situsweb harus menerima banyak pengunjung dalam waktu yang bersamaan dan masalah utamanya yaitu frekuensi sinyal yang dapat terganggu akibat cuaca yang buruk, selain itu frekuensi sinyal tidak dapat dijangkau sampai ke pelosok pedesaan. Karena keterbatasan menjadi hambatan dalam berkomunikasi jarak jauh. Tidak hanya kekurangan yang dimiliki oleh internet, tetapi internet juga memiliki kelebihan yaitu internet juga dapat membantu, sebagai penunjuk arah ke tempat yang dituju. Seperti aplikasi CNN, Peta Mudik dan yang terbaru saat ini adalah "Metro traffic".

Aplikasi "Metro traffic" adalah terobosan baru bagi para pengguna jalan khusus nya pengguna jalan jarak jauh. Aplikasi yang di keluarkan oleh salah satu stasiun tv yaitu METRO TV digunakan sebagai branding untuk menarik minat dan meningkatkan citra di hadapan masyarakat Indonesia. Aplikasi yang baru di launching pada tahun 2017 ini dibuat oleh biro iklan SOCIO KOMUNIKASI dengan konsep kreatif yang bertujuan untuk memberi kemudahan kepada para pemudik yang ingin pergi ke kampung halaman nya atau para pengguna jalan yang ingin pergi tamasya keluar kota. Karena di aplikasi ini terdapat fitur-fitur yang lebih lengkap di bandingkan dengan aplikasi-aplikasi yang lain.
Fitur yang berbeda atau yang lebih lengkap dari aplikasi ini tidak lepas dari konsep kreatif seorang Creative Director yang membuat sebuah konsep kreatif pada aplikasi "Metro Traffic" dengan menggunakan fitur-fitur yang lebih lengkap dan menarik. Creative Director harus memadukan sebuah konsep kreatif nya dengan Brief dari klien nya tersebut. Tidak mudah untuk memadukan ide si kreator dengan brief dari klien. Disini tantangan untuk seorang Creative Director untuk menyatukan ide-ide brilian nya dengan apa mau dari klien tersebut. Apabila sudah menyatu ide dari Creative Director dengan Brief dari klien tersebut maka tercipta lah sebuah konsep yang kreatif seperti aplikasi "Metro Traffic" dangan fitur-fitur nya yang unik dan sederhana yang bertujuan untuk mempermudah para penggunanya agar tidak terjadi kebingungan saat ingin berpergian, contoh nya seperti menampilkan rest area yang berada di dekat para penggunanya apabila mereka ingin beristirahat sejenak. Banyak terdapat tempat makan seperti restoran atau rumah makan yang ditampilkan pada aplikasi ini. Aplikasi "Metro Traffic" menampilkan tempat makan terdekat bagi para pemudik atau pengguna jalan yang ingin mengkonsumsi makanan terlebih dahulu sebelum melanjutkan perjalanan nya, tempat pengisian bensin pun tidak luput di tampilkan di aplikasi ini karena penting bagi pengguna kendaraan untuk mengisi bahan bakar kendaraan nya agar tidak kehabisan bensin di dalam perjalanan dan tempat untuk beribadah.

Fitur ini juga penting bagi para pemudik atau pengguna kendaraan untuk beribadah dikarenakan cukup sulit untuk menemukan tempat ibadah disaat perjalanan, terkadang pula pemudik atau pengguna jalan terlewat karena tidak sempat berhenti, tidak hanya itu aplikasi ini juga dapat menampilkan lokasi pengguna aplikasi dan jalur mana saja yang terdapat kemacetan.

Aplikasi "Metro Traffic" sangat memberikan kenyamanan bagi para penggunanya karena sang Creative Director 


\section{Jurnal Ilmiah Komunikasi}

sengaja membuat konsep kreatif pada aplikasi "Metro Traffic" dengan tujuan untuk memberikan kenyamanan dalam menggunakan aplikasi "Metro traffic" bagi pemudik atau pengguna kendaraan agar selamat sampai dengan tujuan. Banyak fitur di aplikasi "Metro Traffic" yang aplikasi lain tidak punya seperti, jadwal penerbangan pesawat, jadwal keberangkatan kapal laut dan jadwal keberangkatan bus, fitur-fitur tersebut yang tidak dimiliki oleh aplikasi-aplikasi lain seperti CNN dan Peta Mudik. Dengan tampilan desain yang tidak terlalu rumit dan aplikasinya mudah di mengerti bagi setiap orang. Dan di dalam aplikasi Metro Traffic terdapat video news yang ada di sekitar kita.

Adapun tujuan dari penelitian ini adalah untuk mengetahui Strategi Kreatif Creative Director Socio dalam Pembuatan Aplikasi Metro Traffic Tahun 2017.

\section{Metode}

Dalam penelitian ini, berdasarkan desain penelitian dengan pendekatan kualitatif dan bersifat deskriptif kualitatif, Satori mengungkapkan bahwa penelitian kualitatif dilakukan karena peneliti ingin mengeksplor fenomena-fenomena yang tidak dapat dikuantifikasikan yang bersifat deskriptif seperti proses suatu langkah kerja, formula suatu resep, pengertian-pengertian tentang suatu konsep yang beragam, karakteristik suatu barang dan jasa, gambar gambar, gaya-gaya, tata cara suatu budaya, model fisik suatu artifak dan lain sebagainya. $^{2}$

Selain itu, Sugiyono juga mengemukakan penelitian kualitatif sebagai metode penelitian yang berlandaskan pada filsafat postpositivisme, digunakan untuk meneliti pada kondisi objek alamiah, dimana peneliti adalah sebagai instrumen kunci, teknik pengumpulan data dengan triangulasi, analisis data bersifat induktif atau kualitatif, dan hasil penelitian kualitatif lebih menekankan makna daripada generalisasi. ${ }^{3}$

Menurut Sukmadinata, penelitian deskriptif kualitatif ditujukan untuk mendeskripsikan dan menggambarkan fenomena-fenomena yang ada, baik bersifat alamiah maupun rekayasa manusia, yang lebih memperhatikan mengenai karakteristik, kualitas, keterkaitan antar kegiatan. ${ }^{4}$ Selain itu, Penelitian deskriptif tidak memberikan perlakuan, manipulasi atau pengubahan pada variabel variabel yang diteliti, melainkan menggambarkan suatu kondisi yang apa adanya. Satu-satunya perlakuan yang diberikan hanyalah penelitian itu sendiri, yang dilakukan melalui observasi, wawancara, dan dokumentasi.

Berdasarkan keterangan dari beberapa ahli di atas, dapat ditarik kesimpulan bahwa penelitian deskriptif kualitatif yaitu rangkaian kegiatan untuk memperoleh data yang bersifat apa adanya tanpa ada dalam kondisi tertentu yang hasilnya lebih menekankan makna.

Penulis menetapkan yang menjadi bahan penelitian dalam penelitian ini adalah strategi kreatif Creative Director dalam pembuatan aplikasi Metro traffic yang ditujukkan kepada para pengguna kendaraan. Menurut Sugiyono "dalam penelitan kualitatif yang menjadi instrumen atau alat penelitian itu sendiri. ${ }^{3}$ Oleh karena itu, peneliti sebagai instrumen juga harus divalidasi seberapa jauh peneliti kualitatif siap melakukan penelitian yang selanjutnya terjun ke lapangan".

Dari kutipan diatas, penulis dapat memahami bahwa unit analisis adalah komponen yang berkaitan dengan masalah pokok dalam penelitian yang bersangkutan. Lebih lanjut, menurut Sugiyono "peneliti kualitatif sebagai human instrument, berfungsi sebagai sumber data, melakukan pengumpulan data, menilai kualitas data, analisis data, menafsirkan data dan membuat kesimpulan atas temuannya". 3 Dari pendapat diatas, penulis memahami bahwa untuk menentukan unit analisis penelitian, harus dikaitkan dengan pertanyaan-pertanyaan pada awal penelitian.

Lokasi penelitian dilakukan di PT. SOCCIO KOMUNIKASI Agency, yang beralamat di Menara Dea, Jl. Mega Kuningan 


\section{Jurnal Ilmiah Komunikasi}

Barat No.1, Kecamatan Setiabudi, RT 5/RW 2, Kota Jakarta Selatan Daerah Khusus Ibukota Jakarta 12950. Penelitian dilaksanakan selama 3 bulan, pada bulan April 2017 sampai Juni 2017. Berikut ini merupakan nama-nama key informan berikut tugas dan wewenang mereka yang peneliti dapatkan dari data Biro iklan Socio Komunikasi.

Nama : Nico Jorano Firdaus Jabatan : Creative Director Tugas dan Wewenang : a) Membuat ide konsep konten kreatif audio visual aplikasi Metro Traffic b) Menjaga konten agar sesuai dengan brief klien c) Menentukan konsep Design d) Menentukan semua hal teknis (Lay $O u t$ ) yang berhubungan dengan konten

Nama : Dedy safiudin Jabatan : Business Development Tugas dan Wewenang : a) Memantau perkembangan pemasaran dalam menjual atau meluncurkan sebah prodouk b) Memperhatikan anggaran belanja yang dialokasikan dalam satu tahun. c) Membuat anggaran kegiatan untuk meluncurkan sebuah produk agar mendapatkan support dari pihak manajemen.

Nama : Mansoor Jabatan : Technical Head Tugas dan Wewenang : a) Mengatur lalu lintas pekerjaan dari Client Service Departement ke Creative Departement b) Membantu Creative Director dalam membagi tugas di Creative Departement. c) Mencatat sebuah nomor pada setiap pekerjaan yang dipesan oleh klien melalui Client Service.

Peneliti melakukan observasi pada saat proses pengemasan konten dan brief dari klien, mulai dari pra, produksi hingga pasca produksi aplikasi Metro Traffic. Peneliti akan melakukan wawancara mendalam atau indepth interview dengan biro iklan yang mengkonsep pembuatan aplikasi Metro Traffic. Dokumentasi yang digunakan peneliti dalam penelitian ini adalah dengan mengambil data dari buku-buku dan catatan catatan.

1. strategi harus di rancang dengan kreatif, dengan menggali segala sesuatu di balik "insight " dan menyusunnya ke arah gagasan yang kreatif, seperti bentuk kreatifitas berupa suatu tindakan yang merupakan hasil pemikiran yang "sadar" maupun "tidak sadar" yang berupa pengetahuan, logika, imajinasi dan intuisi.

2. strategi kreatif bukan semata-mata menyangkut soal proses logika tetapi tentang proses seni.

Data yang telah dikumpulkan oleh peneliti akan diatur, diurutkan dan di kelompokan. Pengorganisasian dan pengolahan data tersebut bertujuan menemukan tema dan hipotesis kerja. Menurut Miles dan Huberman terdapat tiga teknik analisisi data kualitatif yaitu reduksi data, penyajian data dan penarikan kesimpulan. Proses ini berlangsung terus-menerus selama penelitian berlangsung, bahkan sebelum data benar-benar terkumpul. ${ }^{5}$

1. Reduksi Data merupakan salah satu dari teknik analisis data kualitatif. Reduksi data adalah bentuk analisis yang menajamkan, menggolongkan, mengarahkan, membuang yang tidak perlu dan mengorganisasi data sedemikian rupa sehingga kesimpulan akhir dapat diambil. Reduksi tidak perlu diartikan sebagai kuantifikasi data.

2. Penyajian Data merupakan salah satu dari teknik analisis data kualitatif. Penyajian data adalah kegiatan ketika sekumpulan informasi disusun, sehingga memberi kemungkinan akan adanya penarikan kesimpulan. Bentuk penyajian data kualitatif berupa teks naratif (berbentuk catatan lapangan), matriks, grafik, jaringan dan bagan.

3. Penarikan Kesimpulan merupakan salah satu dari teknik analisis data kualitatif. Penarikan kesimpulan adalah hasil analisis yang dapat digunakan untuk mengambil tindakan.( Sutopo dan Arief ). ${ }^{6}$

\section{Hasil dan Pembahasan}

\section{Strategi Kreatif Creative Director dalam pembuatan aplikasi Metro Traffic}

Langkah awal dalam memproduksi strategi kreatif aplikasi metro traffic yaitu dengan melakukan observasi. Melakukan 


\section{Jurnal Ilmiah Komunikasi}

observasi ini dimaksudkan untuk mendapatkan landasan dasar cerita yang akan dibuat. Karena dengan adanya landasan tersebut kita dapat menemukan berbagai masalah-masalah dan berbagai sentimen yang terjadi terhadap aplikasi Metro Traffic agar pesan yang ingin disampaikan tepat dan tidak menyimpang dari brief yang sudah dibuat oleh klien. Observasi ini dilakukan melalui beragam medianya, bisa secara interview individu, riset dengan cara online seperti menjelajah di media sosial. Pada proses ini biasanya dilakukan oleh digital analis,

Jika kita memperoleh brief dari klien biasanya saya selaku Creative Director nilai apa yang mau dibentuk dan disampaikan kepada audience, kemudian mencari insight dan sentimen yang baik dan tidak baik tentang brand yang akan kita tangani, jika sudah memperoleh hasilnya, lalu di diskusikann dengan digital strategic akan dimana saja placementnya dan angle story mana yang ingin di angkat, agar tidak menjadi salah ataupun keliru dalam menyampaikan pesan.

Dari kutipan wawancara di atas penulis dapat menyimpulkan bahwa sebelum menentukan ide pesan ataupun dasar cerita ini harus didasarkan dengan problem ataupun insight yang matang agar pesan yang ingin disampaikan dalam iklan jelas dan to the point. Insight adalah suatu wawasan orang banyak terhadap brand ataupun merk yang ingin kita cari, yang hasilnya bisa berupa sentimen negatif ataupun positif. Dalam kasus ini brand yang sedang di analisis ialah Metro Traffic Setelah kita memperoleh berbagai insight, hasilnya akan disajikan bisa berupa diagram ataupun persentase yang bersifat confidential, dari diagaram itu kita akan tau seberapa sentimennya suatu brand atau merek dimata audience. Dan dengan adanya diagram itu dapat membantu untuk mempermudah kita mencari dan membentuk ide kreatif yang akan kita sampaikan. Selepas dari hal itu untuk menarik para pengguna, apa saja yang harus dilakukan dalam pengemasan strategi kreatif tersebut, karena menarik perhatian dari penonton juga sangat penting dan harus dirancang dari awal. Karena keberhasilan suatu aplikasi dapat diukur dari seberapa besar pesan yang telah diterima oleh pengguna.

Kalau dari insight nya sudah benar dan tepat, kita mau membuat ide nya lebih mudah. Karena proses kreatif itu sesimple cari insightideas-act. Kemudian di tahap pencarian ide ini kita juga harus benar benar kerucutkan lagi, berdasarkan insight nya, karena kalau masih terlalu luas pun juga nanti tidak akan menjadi efektif. Karena kita tau Metro TV sebelumnya citranya dipandang sebagai stasiun televisi, jadi kita harus mencari akal bagaimanapun SOCIO KOMUNIKASI harus membuat sebuah aplikasi dengan dikemas menjadi menarik tentunya. Setelah itu kita membuat brief untuk diberikan kepada copy writer untuk menuliskan sebuah konten agar pemakai nyaman menggunakan aplikasi tersebut.

Dari kutipan di atas, penulis akan menjelaskan beberapa istilah arti kata brief disini adalah suatu laporan ringkas yang menuntun. Kemudian arti insight ialah suatu wawasan yang terkait dengan brand atau merk yang akan kita teliti. Setelah dari insight kemudian ke penentuan ide cerita sudah terlalui, proses produksi konten berjalan berdasarkan timeline yang sudah ditentukan dalam project timeline.

Dalam proses produksi kontennya pun sendiri ada hal hal yang harus diperhatikan agar tidak terjadi penyampaian yang diluar dari standar. Melewati tahapan research, karena dengan itu kita bisa langsung to the point menyampaikan pesan di aplikasi itu, dan tambahan berupa masukan dari Creative Director mengenai do and don't nya jadi tambah lebih memudahkan lagi. Ya walaupun nantinya akan ada revisi sedikit dari klien. jika kita telah mengikuti proses tiga hal tadi insight-ideas-act. Seperti kutipan Nico Jorano selaku Creative Director konten kreatif dalam kutipan wawancara sebagai berikut Pentingnya suatu pemahaman konsep yang diinginkan oleh klien dan memikirkan sebuah ide yang cocok dengan 


\section{Jurnal Ilmiah Komunikasi}

tema aplikasi tersebut setelah itu baru kita memulai sebuah produksi. 3 tahapan strategi kreatif ini dapat mempengaruhi kualitas strategi yang diproduksi, karena setelah semua berjalan sesuai dengan fungsinya masing masing.

yang pertama itu kita mencari tahu apa yang kita ingin buat sebuah iklan televisi kah, iklan youtube kah atau sebuah aplikasi, setelah itu baru kita mencari ide apa yang cocok dengan tema yang sudah di tentukan seperti metro traffic ini dan konten yang seperti apa yang cocok dengan aplikasi seperti Metro Traffic ini, baru kita melakukan produksi nya seperti mendesain layout nya membuat animasi nya sampai melakukan kodingan untuk web nya setelah itu semua selesai baru kita melakukan pitching ke klien apakah ada revisi atau tidak kalau tidak kita bisa melakukan finishing nya yaitu merapikan bagian-bagian ada cacat nya entah itu pada layout nya atau pada konten aplikasi nya.

kutipan diatas semakin memperkuat langkah awal dalam pembuatan aplikasi harus observasi terlebih dahulu agar kita tahu apa yang ingin kita buat dan meminimalisir terjadinya kesalahan, informasi ini dinyatakan oleh informan 2. Jessica Helfand mengatakan, "Kombinasi kompleks kata-kata dan gambar, angka-angka dan grafik, foto-foto dan ilustrasi yang membutuhkan pemikiran khusus dari seorang individu yang bisa menggabungkan elemen-eleman ini, sehingga mereka dapat menghasilkan sesuatu yang khusus, sangat berguna, mengejutkan atau subversif atau sesuatu yang mudah diingat".

hasil strategi kreatif akan di kompilasi, kemudian dijadikan satu menjadi proposal yang akan di presentasikan kepada klien. Begitupun juga pada penerapan strategi konten yang diarahkan untuk dapat menarik sebanyak mungkin pengguna kendaraan atau pengguna Handphone sesuai dengan segmen yang sudah di tentukan, dan berikut adalah format kreatif Aplikasi Metro Traffic : Judul Tema : Metro Traffic, Target Audience : A, B dan C usia 18 hingga 50 tahun.
Pemilihan judul kreatif Metro Traffic ini tercipta agar memudahkan pemudik atau pengendara dalam melakukan perjalanan jauh, dan setiap konten kreatif yang ada di aplikasi ini tampilan depan diberi Logo Metro Traffic dan di tambahkan nama Metro Traffic dan dengan fitur-fitur yang menarik. Seperti yang ditegaskan oleh Asep kusnaidi selaku Copy Writer:

Dalam membuat judul kita mau yang lebih simple dan mudah di ingat orang, tidak berteletele dan langsung ke intinya. Dengan judul Metro Traffic maka orang bisa tahu apa yang dilakukan oleh Metro TV saaat ini dan kita masih kawan lama yang bisa kamu andalkan.masalah penamaan itu sebenarnya kita hanya menyesuaikan dari klien kita yaitu Metro TV yang saat itu ingin membuat sebuah inovasi baru dengan berbentuk sebuah aplikasi traffic yang ditujukan untuk pemudik, awal nya karna pada saat itu pas bertepatan dengan bulan ramadhan, saya langsung mempunyai ide dengan penamaan aplikasi itu dan saya langsung memeberitahu kepada klien saya "saya sudah punya nama untuk aplikasi ini" saya langsung bilang seperti itu klien saya yang dari Metro TV itu langsung penasaran dan bertanya kepada saya dan saya langsung jawab nama aplikasi nya itu adalah Metro Traffic dan saya langsung menjelaskan arti dari nama Metro Traffic.

Menurut kutipan diatas penulis dapat menyimpulkan bahwa penetuan judul sebuah produk harus yang mudah diingat agar khalayak mudah mengingat dan setelah mengingat diharapkan khalayak mengunduh aplikasi Metro Traffic, seperti yang dituturkan oleh informan 1 .

Kalau untuk siapa yang menentukan nama aplikasi Metro Traffic ini biasanya dari klien mas tetapi ada juga yang dari kita mas. Cuma kalau aplikasi Metro Traffic ini yang memberi nama itu kita mas.

Dalam membuat judul kita mau yang lebih simple dan mudah di ingat orang, tidak berteletele dan langsung ke intinya. Dengan judul 


\section{Jurnal Ilmiah Komunikasi}

Metro Traffic maka orang bisa tahu apa yang dilakukan oleh Metro TV saaat ini.

Sama halnya yang dikatakan oleh informan 2, bahwa dalam pemilihan judul itu harus yang simple agar mudah diingat oleh khalayak.

Target audience kita untuk semua Genre laki-laki wanita dan dari usia 18 hingga 50 tahun. Dan saat ini kita fokus pada mereka audience di digital, karena netizen digital menjadi target utama, karena itu kita memilih Aplikasi sebagai salah satu medianya agar dapat merangkul generasi millenial juga, berdasarkan riset biro iklan pun maka media yang paling efektif ialah video, dan aplikasi.

Dari kutipan di atas, penulis dapat menyimpulkan target dan segmen dapat memepegaruhi media yang akan menjadi target utama dimana hasil dari strategi konten itu akan di upload dan di publish. Dalam hal ini generasi millenial yang menjadi target utama dari Metro TV. proses produksi berlangsung ada beberapa hal yang perlu dilakukan diantaranya ialah mempersiapkan presentasi sebelum Pembuatan aplikasi kepada klien atau brand manager METRO TV. Seperti yang dijelaskan oleh informan 1 dalam kutipan wawancara berikut.

kalo masalah brief client sih sudah pasti mas, biro iklan manapun juga pasti melakukan brief client karna kalau tidak melakukan brief client kita tidak tahu apa yang diinginkan klien kita bekerja juga untuk klien bukan kemauan kita sendiri makanya kita pasti menggunakan brief client.

Brief klien sangatlah penting dilakukan karena dari situ kita bisa memahami apa yang diinginkan dari klien, agency selalu mengutamakan kemauan seorang klien agar klien tidak kecewa dengan hasil yang kita buat. Seperti yang diungkapkan oleh informan 2.

Proses ini sangat penting karena dengan adanya tahap ini dapat memudahkan dalam membentuk satu persepsi antara pihak agency dan klien, dengan harapan strategi pesan yang ingin kita sampaikan tepat pada sasaran. Mulai dari pemilihan cerita, pemilihan media, kemudian insightnya harus tepat agar penerapan strategi tidak terlalu blur atau jauh.

Dari kutipan wawancara di atas, penulis dapat menyimpulkan bahwa kerja sama antara biro iklan dan klien harus terjalin dengan baik, agar dapat menghasilkan strategi yang sesuai dengan tujuan yang sama. Setelah semua proses analisis dan kreatif, sudah dijalani, kini saatnya melihat performa dengan konten yang kreatif. Dengan harapan tahap ini adalah tahap evaluasi agar konten kreatif aplikasi Metro Traffic berikutnya akan lebih baik. Seperti yang dijabarkan oleh informan 1 .

kesulitan nya yaitu pertama mencari ide untuk tampilan seperti apa yang baik dan bagus untuk sebuah aplikasi ini, kedua setelah menemukan sebuah ide nya bagian sulitnya adalah bagaimana kita sebagai Creative Director menyatukan pikiran kita dengan klien kita dan tim kreatif itu bagian tersulit menurut saya karna setiap menusia mempunyai pemikiran yang berbeda beda jadi saya harus berusaha bagaimana caranya bisa menyatukan pemikiran klien dan tim kreatif dengan pemikiran saya itu.

Dari kutipan diatas penulis dapat menyimpulkan bahwa membuat sebuah aplikasi tidak lah mudah karna butuh yang namanya sebuah imajinasi yang tinggi agar hasilnya dapat mencapai target yang diinginkan dan yang tersulitnya adalah menyaatukan sebuah pemikiran, pernyataan tersebut di sampaikan oleh informan 1. "Visual communication (komunikasi visual) adalah latihan teori dan konsep-konsep melalui terma-terma visual dengan menggunakan warna, bentuk, garis dan penjajaran".Pada dasarnya untuk menciptakan karya desain grafis yang bagus, seni dan taste adalah dua hal yang perlu dikedepankan. Selain itu, mempelajari teori dan teknik juga tidak kalah pentingnya agar karya yang dihasilkan menjadi sebuah masterpiece. ${ }^{10}$

bagian tersulit yang saya pernah alami selama saya bekerja di biro iklan ini sih ya menyatukan pikiran dengan tim kreatif yang lain mas karna semuanya mempunyai pendapat yang 


\section{Jurnal Ilmiah Komunikasi}

berbeda beda mas kita harus bisa menyatukan semua pemikiran kita dengan teman satu tim kita dan satu yang dibilang lumayan sulit yaitu pada saat mendesain layout kita perlu konsentrasi tinggi agar hasilnya memuaskan untuk membuat sebuah produk yang bagus pasti kita memeerhatikan detail-detail pada produk tersbut kurang detail nya satu saja akan mengurangi nilai pada produk yang kita buat dan kalo klien kurang puas dengan hasil kerja kita klien bisa kecewa dengan kita dan tidak akan menggunakan jas kita lagi.

Sama hal nya yang dikatakan oleh informan 1 menyatukan pemikiran bagian tersulit karena bekerja dengan tim lebih sulit dibandingkan bekerja individu, bekerja dengan kita harus menyatukan pemikiran masingmasing agar tujuan yang diinginkan tercapai, pernyataan yang dituturkan oleh informan 2 .

\section{Kesimpulan}

Dari keseluruhan pernyataan diatas yang telah penulis sampaikan, maka kesimpulan yang dapat disampaikan adalah tiga tahapan yang sangat penting dilakukan pada biro iklan SOCIO KOMUNIKASI yaitu insight - ideas - act, tahapan ini sebagai dasar dari sebuah ide pembuatan aplikasi Metro Traffic yang akan kita sampaikan kepada audience, berikut penjelasan dari ketiga tahapan tersebut.

Insight (observasi), tahap ini merupakan tahapan sebuah research ataupun pencarian dari berbagai macam sentimen dapat berupa informasi positif ataupun negatif, setelah memperoleh hal tersebut langkah berikutnya, membentuk ide awal dari suatu strategi kreatif aplikasi. pada tahapan ini sebuah informasi yang sudah didapat akan dikelola dengan cara memilah informasi mana yang bisa digunakan untuk menjadi sebuah ide yang kemudian ide tersebut menjadi sebuah kunci ide dalam pembuatan sebuah aplikasi Metro Traffic, kemudian. Act (aksi), aksi yang dimaksudkan disini adalah sebuah tahapan produksi pembuatan aplikasi sebagai berikut :

Menentukan isi pada halaman aplikasi Metro Traffic, pada bagian ini tugas dari seorang
Copywritter lah yang dapat menentukan isi dari sebuah aplikasi ini, Copywritter menentukan isi dari halaman depan sampai halaman akhir aplikasi Metro Traffic. Jessica Helfand mengatakan, "Kombinasi kompleks kata-kata dan gambar, angka-angka dan grafik, foto-foto dan ilustrasi yang membutuhkan pemikiran khusus dari seorang individu yang bisa menggabungkan elemen-eleman ini, sehingga mereka dapat menghasilkan sesuatu yang khusus, sangat berguna, mengejutkan atau subversif atau sesuatu yang mudah diingat". Dengan demikian maka langkah biro iklan SOCIO KOMUNIKASI analitic, ideas, act sudah tepat sesuai dengan teori Graham Wallas dalam strategi kreatifnya yang menyatakan sebagai berikut :

Inkubasi, yaitu proses mengembangkan ide atau gagasan. Illuminasi, upaya mencari pemecahan masalah. Verifikasi, yaitu upaya memperbaiki ide atau gagasan dan menentukan jika ide atau gagasan tersebut merupakan solusi yang tepat.

\section{Saran}

Dari keseluruhan kesimpulan diatas yang telah penulis sampaikan, maka saran yang dapat disampaikan adalah tiga tahapan yang sangat penting dilakukan pada biro iklan SOCIO KOMUNIKASI yaitu insight - ideas - act, tahapan ini sebagai dasar dari sebuah ide pembuatan aplikasi Metro Traffic yang akan kita sampaikan kepada audience. Terlebih dari itu adapun beberapa saran dan masukan tersebut adalah SOCIO KOMUNIKASI dan dari pihak klien yaitu Metro tv harus perlu mensosialisasikan kepada calon pengguna dan yang paling penting map yang ada di aplikasi tersebut harus diperbaharui, agar masyarakat yang ingin menggunakan aplikasi ini mengerti bagaimana cara mengunakan aplikasi Metro Traffic dan bisa mempermudah pengguna kendaraan yang ingin berpergian jauh terutama yang berpergian ke daerah pelosok. 


\section{Jurnal Ilmiah Komunikasi}

\section{Daftar Pustaka}

1. Morissan. "Manajemen Media Penyiaran: Strategi Mengelola Radio dan Televisi". Kencana Prenada Media Group. Jakarta. 2008.

2. Djam'an Satori. Metode Penelitian Kualitatif, Bandung. Alfabeta. 2011.

3. Sugiyono. Metode Penelitian Kuantitatif Kualitatif dan R\&D. Bandung: Alfabeta. 2012.

4. Nana Syaodih Sukmadinata. Metode Penelitian Pendidikan. Bandung: PT Remaja Rosdakarya. 2011.

5. Emzir. Metodologi Penelitian Pendidikan: Kuantitatif dan Kualitatif. Jakarta: Rajawali Pers. 2010.

6. Ariesto Hadi Sutopo dan Adrianus Arief, Judul: Terampil Mengolah Data. Kualitatif. Penerbit Prenada Media Group : Jakarta. 2010.

7. Widyatama, Rendra. (2007). Pengantar periklanan. Buana pustaka Indonesia Jakarta.
8. Weber, Larry. Marketing to the social web: how digital costumer communities build your business. Hoboken, wiley. New Jersey; 2009.

9. Moriarty, Sandra. Creative advertising theory and practice. Prentice Hall. Engelwood Cliffs.

10. Kusrianto, Adi Pengantar Desain Ilmu Komunikasi Visual. Andi. Jakarta. 2007.

11. Jessica Helfand. 2010. She is a member of the Alliance Graphique Internationale (AGI) And a recent inductee into the art Directors Club Hall of Fame. New York, 2010.

12. Moriarty Sandra. Advertising. Kencana. Jakarta. 2009.

13. Rhenal Kasali. Manajemen Periklanan, Konsep dan Aplikasinya di Indonesia. Pustaka Utama Grafiti. Jakarta 2007. 